ENTREPRENEURSHIP AND SUSTAINABILITY ISSUES

ISSN 2345-0282 (online) http://jssidoi.org/jesi/ 2019 Volume 7 Number 1 (September) http://doi.org/10.9770/jesi.2019.7.1(2)

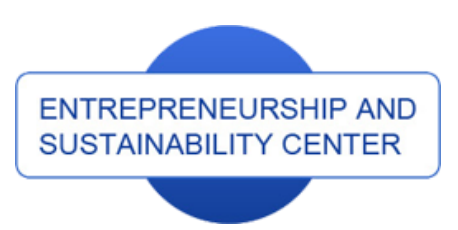

Publisher

http://jssidoi.org/esc/home

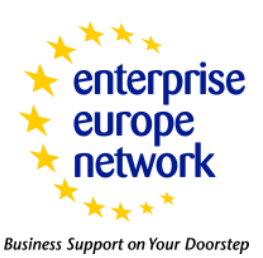

CASPA

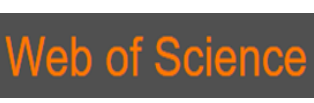

Clarivate
Analytics

\title{
ANALYSIS OF CONSUMER PREFERENCES RELATED TO THE USE OF DIGITAL DEVICES IN
} THE E-COMMERCE DIMENSION*

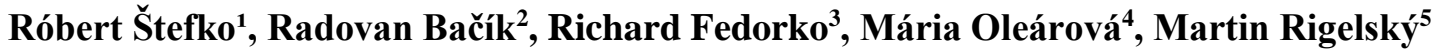 \\ 1,2,3,4,5 University of Prešov, Faculty of Management, Konštantínova ul. 16, 08001, Prešov, Slovakia \\ ${ }^{1}$ robert.stefko@unipo.sk; ${ }^{2}$ radovan.bacik@unipo.sk; ${ }^{3}$ richard.fedorko@unipo.sk; ${ }^{4}$ maria.olearova@smail.unipo.sk; \\ 5 martin.rigelsky@smail.unipo.sk
}

Received 20 March 2019; accepted 5 July 2019; published 30 September 2019

\begin{abstract}
The paper deals with investigating thorough analysis that reveals the impact of digitalisation as the development of new communication platforms are changing consumer's purchasing behaviour in the online environment. The main aim of our research is to identify the dynamics of consumer preferences in relation to the communication platforms of digital equipment for purchase in the online environment. To fulfil the aim of the research we are in the period of February - June 2016 conducted a questionnaire survey located across the whole territory of Slovakia. The sample is representative of the Slovak population by gender, age, highest education level of economic activity. For data analysis we used appropriate methods. This article provides information about consumer preferences related to the use of digital devices when people do their shopping online via the Internet. Depending on the results of the analysis, it can be stated that the most preferred device is the notebook for both groups of respondents surveyed, statistically significant gender differences were not detected. The paper includes practical implications particularly for business entities, because knowledge of the options that digital technology conceals leads to the right set of strategies and will follow the effective achievement of business aims. The paper gives attention to do the role brands and marketers, if he wants to succeed in today's extremely competitive battle for customers to identify deeply rooted motives as well as and preferences of consumers.
\end{abstract}

Keywords: online shopping; e-business; e-commerce; smartphone; tablet; Slovakia

Reference to this paper should be made as follows: Štefko, R.; Bačík, R.; Fedorko, R.; Oleárová, M.; Rigelský, M. 2019. Analysis of consumer preferences related to the use of digital devices in the e-commerce dimension, Entrepreneurship and Sustainability Issues 7(1): 25-33. http://doi.org/10.9770/jesi.2019.7.1(2)

JEL Classifications: M10, M15, M19

Additional disciplines: Information and Communication

\footnotetext{
* This article is one of the partial outputs under the scientific research grant VEGA 1/0789/17 „Research of e-commerce with relation to dominant marketing practices and important characteristics of consumer behavior while using mobile device platforms"and VEGA 1/0609/19 „Research on the development of electronic and mobile commerce in the aspect of the impact of modern technologies and mobile communication platforms on consumer behaviour and consumer preferences ".
} 


\section{ENTREPRENEURSHIP AND SUSTAINABILITY ISSUES}

ISSN 2345-0282 (online) http://jssidoi.org/jesi/

2019 Volume 7 Number 1 (September)

http://doi.org/10.9770/jesi.2019.7.1(2)

\section{Introduction}

It is important to note that often the term e-commerce is confused with the concept of e-business, which is significantly differentiated. Their distinction is explained by one of the biggest marketing experts, according to Kotler (2007) e-business includes all the electronic exchanges of information in the company or between the company and the customer and, on the other hand, e-commerce represents the process of buying and selling supported by electronic means, primarily via the Internet. E-commerce dates back to the 1960s when the development in the field of electronic data interchange, EDI (Electronic Data Interchange) has enabled the exchange/transfer of business documents between computers (Tian \& Stewart, 2008). E-commerce is any transaction that takes place via the computer network and results in the transfer of ownership or rights to use goods or services (Delina \& Vajda, 2008). E-commerce can be considered as a system allowing a direct connection of key business entities, i.e. between the seller and customer to make their business relationships more attractive, through the use of electronic networks to enable day-to-day business activities such as payments or delivery of goods and providing the service (Bhasker, 2013; Bačík et al., 2014). It should be added that ecommerce is not limited to make purchases or sales of goods. E-commerce is a whole range of digital technologies that enable electronic communication (Chaffey, 2009; Štefko et al., 2010). Clemente (2004) explains e-commerce as a concept that refers to active marketing and also to the sale of goods and services on the Internet. Lawson (2015) claims that e-commerce means freedom. Freedom to do business without being in the same room or even in the same country.

\section{Review of Past Studies}

The advantage of e-commerce according to Buttla (2009) is that companies have experienced higher revenues that have been achieved by lowering operating costs, increased sales, but also the possibility of selling advertising space or, even according to Combe (2006), some companies operate e-shops due to presumption that it is a new interactive communication channel. With the ongoing trend of globalization, supply chain management is increasingly becoming more complex for businesses (Šoltés \& Gavurová, 2010). Operations managed by experts are now largely automated (Curtis \& Cobham 2012; Gavurova et al., 2017). In most cases, the authors agree on the benefits of e-commerce. For each of them, however, the most important advantage is in something else. Schneider (2011) considers the greatest benefit in terms of revenue growth and cost savings. The economic benefits of e-shopping are explained by Manzoor (2010), with the variable cost per unit of digital products being in most cases very low and the fixed costs spread over multiple units, which ultimately reflects revenue growth as well as increased sales. Chromný (2009) also notes a reduction in warehouse inventory and therefore smaller warehouse space, which at the same time leads to a reduction in rental and overheads, and at the same time a lower number of necessary staff and thus lower wage costs.

E-commerce has provided many new opportunities for consumers (Hajli, 2014; Androniceanu et al. 2017; Raudeliūnienè et al., 2019; Pogodina et al., 2019). The rapid expansion of Internet, e-commerce and social media has made the study of consumer behaviour in e-commerce and fundamental research agenda (Liang \& Turban, 2011). E-commerce and social media are likely to develop marketing strategies through trust-building mechanisms and affecting customers' intention to purchase online products or to churn. In fact, the rapid growth of e-commerce raises important research questions about the levels of loyalty and churn management in the web environment. This rapid growth reflects the compelling advantages that e-commerce and social media offer over conventional physical stores, including easier interconnectivity and participation on the web (Mueller, et al., 2011). These advancements have developed social commerce into a vibrant and lucrative e-commerce channel, highlighting this is an important point as a customer involvement through social media, which is a key factor in the development of new marketing strategies (Park et al., 2007). 


\section{ENTREPRENEURSHIP AND SUSTAINABILITY ISSUES}

ISSN 2345-0282 (online) http://jssidoi.org/jesi/ 2019 Volume 7 Number 1 (September) http://doi.org/10.9770/jesi.2019.7.1(2)

\section{Methodology}

The main goal of the research was to identify the dynamics of consumer preferences in relation to communication platforms and digital devices when purchasing in the online environment. For a more detailed specification of their changing shopping habits, we have also decomposed the main research target at these sub-targets:

- Identify consumer preferences related to the use of digital devices when performing various online activities.

- Find out what kind of devices are used by respondents when they are buying products online.

Based on the main and partial objectives of our research, the following hypothesis was formulated: H1: Gender differences in the use of digital devices are statistically significant when people buy products online.

In order to meet our defined research goal, we conducted a questionnaire survey in the Slovak Republic between February and June 2016. Due to incomplete completion, 23 questionnaires were excluded. The data obtained was evaluated using the Microsoft Office package, in particular the Excel spreadsheet editor. The IBM SPSS Statistical Software was used for mathematical and statistical analyses. Due to the scale of the questionnaire, we used simultaneous parallel profile testing and correlation analysis.

The research sample obtained within the questionnaire survey can be considered representative in relation to the Slovak population. The survey consisted of 414 respondents, of which up to 256 (62\%) were women and 158 (38\%) men. Respondents were, in terms of the age cohorts, divided into consumers so called X generation (36-52 years) with $72 \%$ representation and $\mathrm{Y}$ generation (16-35 years) with a $28 \%$ representation. The group of respondents with a basic level of education was exactly 10 respondents. Respondents with secondary education without school leaving examination had 14 respondents (3\%) and with a school leaving examination 156 (38\%). More than half of the respondents $(57 \%)$ involved in the survey were people with university education. At the same time, it is also the most numerous group of all respondents. In terms of economic activity, the survey was attended by almost the same number of employees working in the public sphere $(26 \%)$ as well as in the private sphere $(27 \%)$. On the other hand, only a little more (in the number of 114 respondents), our survey sample consisted of students representing $28 \%$ of all respondents. The group of self-employed or entrepreneurs accounted for $13 \%$ of the respondents. The survey was also filled by unemployed people, who formed less than $4 \%$. The entry "Other" was marked by 14 respondents. Among them were women on maternity leave or men on parental leave, disabled, retired people, a truck driver, a community worker, or people working abroad.

\section{Result}

Relevant outcomes from the survey are declared in the following sections of this article. One of our questions was which digital devices respondents preferred to perform selected online activities. According to the fact, that respondents did not choose any of the options for some items, we assume they do not perform those activities. The strong penetration of mobile devices in the Slovak market may have increasing potential, but the results of the research reveal that more people prefer laptops instead of smartphones for various online activities. In the case of all three activities to which we have drawn our attention, it is clear that both generations prefer the above mentioned notebook. When searching for general information, one third of women prefer smartphones and only $26.58 \%$ of men prefer smartphones. Only $5.47 \%$ of women search for information using tablets, while tablets among men are slightly popular (13.92\%). However, notebooks are the most popular. Almost half of the men $(48.10 \%)$ surveyed and more than half of the women $(53.91 \%)$ search for information online using notebooks. 
When searching for information about products, it is similar to the one in the previous case, as the notebook is dominating among the respondents. $24 \%$ of women use smartphones to look for information about products. Only $7 \%$ of women prefer tablets, and the vast majority of women (almost 60\%) prefer to search for information about products using a laptop. Nearly $22 \%$ of men prefer their smartphones to search for information, $10.13 \%$ use tablets, and as in the case of women, more than half of the men prefer notebooks.

Even when purchasing products of reflected in Table 1 and Figure 1, it is clear that consumers still prefer notebooks instead of smartphones and tablets. For women, it is up to $75 \%$, and $67 \%$ of men buy from e-shops more often using a notebook. The research also points to the fact that women use smartphones to search for general information and not to buy products. The situation is the same with men. Tablets are generally the least used digital devices, but women use them to search for information about products (7\%), while twice as many men use tablets to search for information of a different character (14\%).

While the notebook is the most used device for purchasing products in the online environment in $75 \%$ of women, on the other hand it is -8 points compared to men.

Table 1. Activities carried out through digital devices (in \%)

\begin{tabular}{|l|c|c|c|c|c|c|}
\hline \multirow{2}{*}{ Activity } & \multicolumn{2}{|c|}{ Smartphone } & \multicolumn{2}{|c|}{ Tablet } & \multicolumn{2}{c|}{ Notebook } \\
\cline { 2 - 7 } & Female & Male & Female & Male & Female & Male \\
\hline Search for general information & 31.25 & 26.58 & 5.47 & 13.92 & 53.91 & 48.10 \\
\hline Search for product information & 24.22 & 21.53 & 7.03 & 10.13 & 59.38 & 54.43 \\
\hline Buying product & 10.16 & 11.39 & 4.69 & 6.33 & 75.00 & 67.09 \\
\hline
\end{tabular}

Source: own elaboration

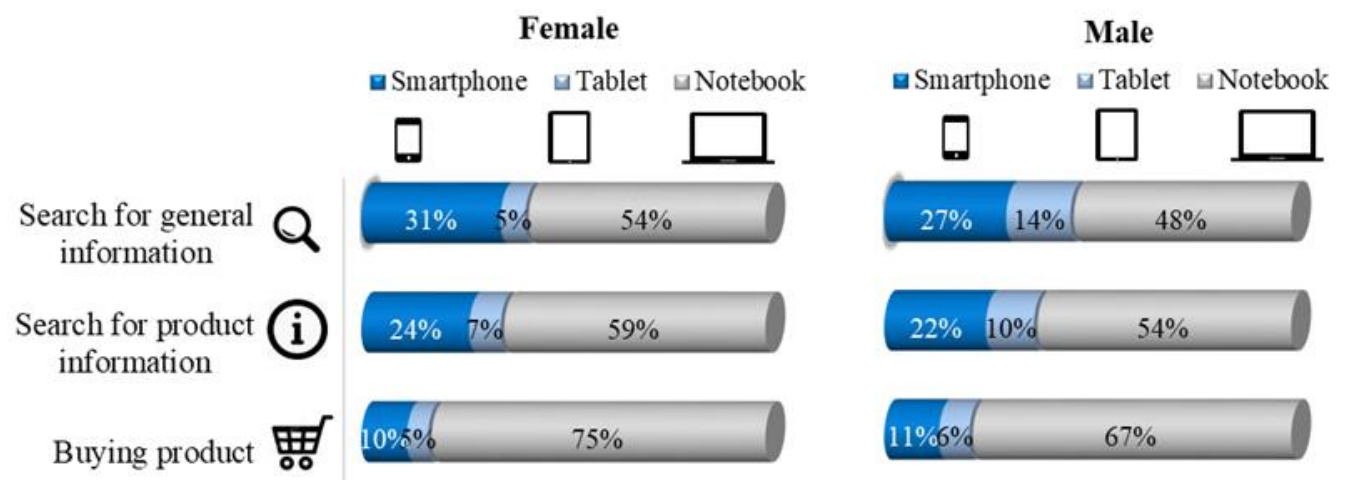

Fig.1. Activities carried out through digital devices

Source: own elaboration

One of our partial goals was to find out which devices buyers use when purchasing online. The results of the analysis show that among the two groups, the notebook is the most preferred one. While it is $60.76 \%$ for men, on the contrary, it goes up to $73.44 \%$ of women in the online environment through this device. The least preferred digital device is the tablet, less than $15 \%$ of women purchase online, and only about a tenth of men. On the contrary, it certainly does not purchase up to $70 \%$ of this device. The results of the analysis, among other things, confirm the fact that the traditional desktop computer has moved into the background, and vice versa, the most prominent places are taken by smaller devices. A substantial majority (62-63\%) for both genders does not use the desktop to purchase products in the online environment. It can not be claimed that ubiquitous smartphones are the 
most popular online shopping devices, but the results of the analysis show that almost a third of men definitely buy through smart phones. The percentage of women in this case is seven points lower.

The results of the present analysis also point to the fact that, for all men and women, the most used device is still the notebook. However, looking at Chart 2, it may be noticed that the second most preferred device for men is the smartphone (26.58\%), while women prefer desktop (23.44\%). However, according to Table 2 and Figure 2, it is worth pointing out that after counting the positive answers (4 and 5), we can assert that even for women, the second most frequently used digital device for online purchasing is the smartphone.

Table 2. Device preferences for online purchasing (in \%)

\begin{tabular}{|c|c|c|c|c|c|c|c|c|c|c|}
\hline \multirow{2}{*}{ Digital device } & \multicolumn{2}{|c|}{ 1-definetly no } & \multicolumn{2}{|l|}{2} & \multicolumn{2}{|l|}{3} & \multicolumn{2}{|l|}{4} & \multicolumn{2}{|c|}{ 5-definetly yes } \\
\hline & $\mathrm{F}$ & $\mathrm{M}$ & $\mathrm{F}$ & $\mathrm{M}$ & $\mathrm{F}$ & $\mathrm{M}$ & $\mathrm{F}$ & $\mathrm{M}$ & $\mathrm{F}$ & $\mathrm{M}$ \\
\hline Smartphone & 59.38 & 53.16 & 6.25 & 3.80 & 5.47 & 10.13 & 9.38 & 6.33 & 19.53 & 26.58 \\
\hline Tablet & 63.28 & 70.89 & 5.47 & 1.27 & 10.16 & 5.06 & 6.25 & 12.66 & 14.84 & 10.13 \\
\hline Notebook & 14.06 & 22.78 & 5.47 & 2.53 & 3.13 & 1.27 & 3.91 & 12.66 & 73.44 & 60.76 \\
\hline Desktop & 63.28 & 62.03 & 4.69 & 2.53 & 3.91 & 7.59 & 4.69 & 6.33 & 23.44 & 21.52 \\
\hline
\end{tabular}

Source: own elaboration

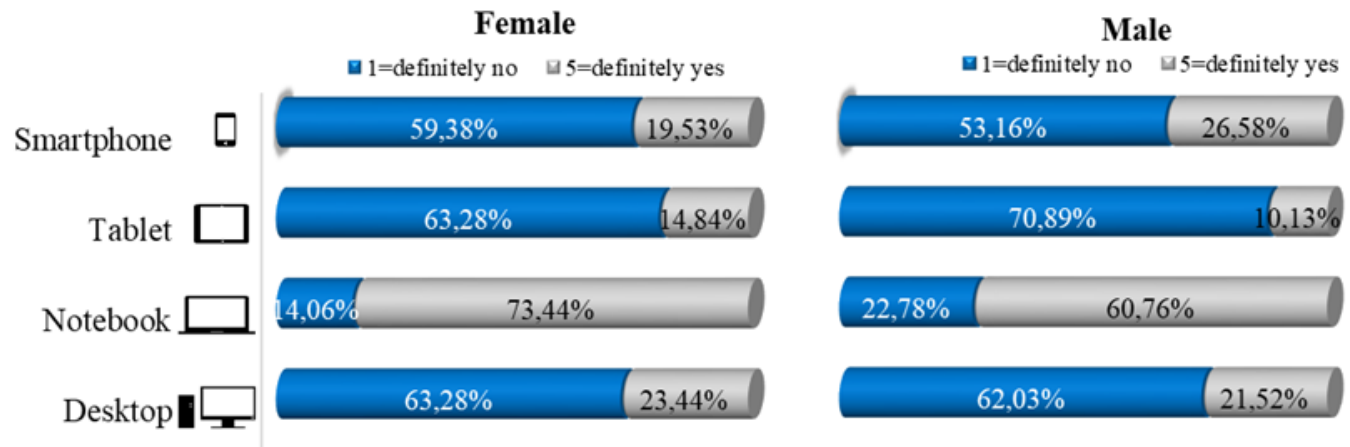

Fig.2. Device preferences for online purchasing from a gender perspective Source: own elaboration

Continuing the investigation we continued to verify the established hypothesis, to which we used a nonparametric parallel test of parallel profiles. The following Table 3 determines the average and standard deviation values defined to the matter under consideration.

Table 3. Average and standard deviation values for purchasing devices

\begin{tabular}{|l|l|l|l|l|l|}
\hline \multicolumn{2}{|l|}{ What kind of digital devices do you use when buying on the Internet? } \\
\hline Gender & & Smartphone & Tablet & Notebook & Desktop \\
\hline \multirow{2}{*}{ Female } & Mean & 2.23 & 2.04 & 4.17 & 2.20 \\
\cline { 2 - 6 } & Std. Deviation & 1.65 & 1.53 & 1.49 & 1.71 \\
\hline \multirow{2}{*}{ Male } & Mean & 2.49 & 1.90 & 3.86 & 2.23 \\
\cline { 2 - 6 } & Std. Deviation & 1.75 & 1.48 & 1.66 & 1.69 \\
\hline \multirow{2}{*}{ Total } & Mean & 2.33 & 1.99 & 4.05 & 2.21 \\
\cline { 2 - 6 } & Std. Deviation & 1.69 & 1.51 & 1.57 & 1.70 \\
\hline
\end{tabular}

Source: own elaboration 
It cannot be clearly stated from this table that the use of devices for purchasing men's and women's products is really different. Rather, it can be seen that the differences are only minimal. The most frequently used devices are notebooks, which are more common among women. The following Table 4 shows us the results of each test. In the final verification of the hypothesis we decide between:

H0: Gender differences in the use of devices to buy products in the online environment are not statistically significant, deviations are only incidental.

H1: Gender differences in the use of devices to buy products online are statistically significant.

Table 4. Testing parallel profiles for using devices to purchase products

\begin{tabular}{|c|c|c|c|c|c|}
\hline \multicolumn{6}{|c|}{ What kind of digital devices do you use when buying on the Internet? } \\
\hline \multirow{9}{*}{$\begin{array}{l}\text { Testing } \\
\text { parallel } \\
\text { profiles }\end{array}$} & & Smartphone & Tablet & Notebook & Desktop \\
\hline & Variable & $\mathrm{t} 1$ & $\mathrm{t} 2$ & t3 & $\mathrm{t} 4$ \\
\hline & RK1t- & 1316 & 1263 & 1706 & 1293 \\
\hline & RK2t= & 838 & 757 & 1012 & 793 \\
\hline & Vt- & -1.345 & 1.323 & 2.205 & 0.252 \\
\hline & Vcrit.- & 2.638 & & & \\
\hline & $\mathrm{pt}=$ & 0.089 & 0.093 & 0.014 & 0.401 \\
\hline & pcorrected & 0.004 & & & \\
\hline & sig- & $\mathrm{NO}$ & $\mathrm{NO}$ & $\mathrm{NO}$ & $\mathrm{NO}$ \\
\hline
\end{tabular}

Source: own elaboration

According to this, in all cases the $\mathrm{V}$ critical level is higher than the absolute value in the statistical one, so for the hypotheses in $\mathrm{t} 1, \ldots, \mathrm{t} 4$ we accept the $\mathrm{H} 0$ zero hypothesis and we therefore accept the opinion that the gender differences in the use of the devices for purchasing the products in the online environment are not statistically significant.

\section{Conclusions}

The most popular interactive medium of the present, Internet, has expanded the perception and character of the economy as a whole. The use of this network has marked all those who have begun to perceive its innumerable possibilities and benefits. With its development, there is also an enormous increase in technology which supports electronic processes, in particular e-commerce and all forms that are inherently associated with it.

The objective of this paper was to identify consumer preferences related to the use of digital devices when searching for product information as well as the online buying process, due to gender differences. In line with the above presented results of the analysis, it can be stated that although smart phones are becoming a regular device for various online activities, Slovak consumers still prefer notebooks. In addition, our survey reveals the fact that the use of digital devices to buy products online is not statistically significant by gender.

Nowadays, when there is no doubt that innovation is synonymous with success, it is crucial to take advantage of all opportunities to strengthen customer relationships, and the real opportunity is to find relevant data which helps marketers focus more accurately on the right group of people. 


\section{ENTREPRENEURSHIP AND SUSTAINABILITY ISSUES}

ISSN 2345-0282 (online) http://jssidoi.org/jesi/ 2019 Volume 7 Number 1 (September) http://doi.org/10.9770/jesi.2019.7.1(2)

\section{References}

Androniceanu A.; Burlacu, S.; Drăgulănescu, I.V.; Nicolae, E.E. New trends of businesses digitalization in Romania and the behaviour young consumers", BASIQ International Conference: New Trends in Sustainable Business and Consumption, 31 May-2 June, 2017 , Graz, Austria, Proceedings of BASIQ, Vol. 01, pp.27-35, Edited by: Rodica Pamfilie, Vasile Dinu, Laurențiu Tăchiciu, Doru Pleșea, Cristinel Vasiliu; ISBN-ISSN 2457-483X ESI

Bhasker, B. 2013. Electronic commerce: framework, technologies and applications. New York: McGraw-Hill Education. https://www.amazon.com/Electronic-Commerce-Framework-Technologies-Applications/dp/9351341674

Buttle, F. 2009. Customer Relationship Management: Concepts and Technology. London: Routledge. https://www.routledge.com/Customer-Relationship-Management-Concepts-and-Technologies-3rd-Edition/ButtleMaklan/p/book/9781138789838

Clemente, M. N. 2004. Dictionary of Marketing: Key Terms and Terms. Prague: Computer press. https://www.amazon.com/MarketingGlossary-Terms-Concepts-Applications/dp/0971943427

Colin, C. 2006. Introduction to e-Business: Management and Strategy. Amsterdam: Elsevier. https://www.amazon.com/IntroductionBusiness-Management-Colin-Combe/dp/0750667311

Curtis, G.; \& Cobham, D. 2005. Business Information Systems: Analysis, Design, and Practice. London: Pearson Education. https://www.amazon.com/Business-Information-Systems-Analysis-Practice/dp/0273713825

Delina, R.; \& Vajda, V. 2008. Theory and Practice of E-commerce. Prešov: Grafotlač Prešov. https://exclusiveejournal.sk/files/files/13/23/84/cc6c4f65a3fb4cc0ad311b667a6aa63c/cc6c4f65a3fb4cc0ad311b667a6aa63c.pdf

Bačík, R.; Szabo, Z. K.; \& Fedorko, R. 2014. The analytical insight into customer perception of quality determinants of the e-commerce model B2C subjects in the central European countries, Quality Innovation Prosperity 18(2): 15-26. http://dx.doi.org/10.12776/qip.v18i2.316

Gavurová, B.; Virglerová, Z.; \& Janke, F. 2017. Trust and a Sustainability of the macroeconomic growth Insights from dynamic perspective, Journal of Security \& Sustainability Issues 6(4): 637-648. https://doi.org/10.9770/jssi.2017.6.4(9)

Govindaraju, R.; \& Chandra, D. R. 2011. E-commerce adoption by Indonesian small, medium, and micro enterprises (SMMEs): Analysis of goals and barriers. Communication Software and Networks (ICCSN), 2011 IEEE 3rd International Conference, ICCSN 2011. May 2729, art. no. 6014861, Xi'an, China, 113-117. https://doi.org/10.1109/ICCSN.2011.6014861

Hajli, M. N. 2014. A study of the impact of social media on consumers, International Journal of Market Research 56(3): 387-404. https://doi.org/10.2501/IJMR-2014-025

Chaffey, D.; Ellis-Chadwick, F.; Mayer, R.; \& Johnston, K. 2009. Internet marketing: strategy, implementation and practice. London, Pearson Education. https://www.amazon.co.uk/Internet-Marketing-Strategy-Implementation-Financial/dp/0273717405

Chromý, J. 2009. Electronic Business. Prague: Institute of Hospitality Management in Prague. http://www.extrasystem.com/9788087570111.pdf

Kotler, P. et al. 2007. Modern marketing. Prague: Grada Publishing.

Lawson, J. 2015, April 13. What is Ecommerce anyway? Webretailer, retrieved from http://www.webretailer.com/lean-commerce/what-isecommerce

Liang, T. P.; \& Turban, E. 2011. Introduction to the special issue social commerce: a research framework for social commerce, International Journal of electronic commerce 16(2): 5-14. https://doi.org/10.2753/JEC1086-4415160201

Manzoor, A. 2010. E-Commerce: An Introduction. Saarbrücken: LAP LAMBERT Academic Publishing. https://www.amazon.com/Commerce-Introduction-Amir-Manzoor/dp/3843370303

Mueller, J.; Hutter, K.; Fueller, J.; \& Matzler, K. 2011. Virtual worlds as knowledge management platform-a practice-perspective, Information Systems Journal 21(6): 479-501. https://doi.org/10.1111/j.1365-2575.2010.00366.x 


\section{ENTREPRENEURSHIP AND SUSTAINABILITY ISSUES}

ISSN 2345-0282 (online) http://jssidoi.org/jesi/ 2019 Volume 7 Number 1 (September) http://doi.org/10.9770/jesi.2019.7.1(2)

Park, D. H.; Lee, J.; \& Han, I. 2007. The effect of on-line consumer reviews on consumer purchasing intention: The moderating role of involvement, International journal of electronic commerce 11(4): 125-148. https://doi.org/10.2753/JEC1086-4415110405

Pogodina, T.V.; Aleksakhina, V.G.; Burenin, V.A.; Polianova, T.N.; Yunusov, L.A. 2019. Towards the innovation-focused industry development in a climate of digitalization: the case of Russia, Entrepreneurship and Sustainability Issues 6(4): 1897-1906. http://doi.org/10.9770/jesi.2019.6.4(25)

Raudeliūnienė, J.; Davidavičienė, V.; Tvaronavičienė, M.; Radeckytė, V. 2018. A study of success factors of women's leadership in ecommerce, Terra Economicus, 16(3):120-138 https://doi.org/10.23683/2073-6606-2018-16-3-120-138

Schneider, G. 2011. E-business. Boston: Cengage Learning. https://www.amazon.com/Electronic-Commerce-Gary$\underline{\text { Schneider/dp/128542543X }}$

Šoltés, V.; \& Gavurová, B. 2010. Modification of performance measurement system in the intentions of globalization trends, Polish Journal of Management Studies 11(2): 160-170. https://pjms.zim.pcz.pl/resources/html/article/details?id=167342

Stefko, R.; Habanik, J.; \& Butoracova-Sindleryova, I. 2010. Marketing Instrumentary in the Process of Project Acceptation within the Acceleration of Back-warded Regions Development, Ekonomicky Casopis 5(58): 512-526. https://www.infona.pl/resource/bwmeta1.element.a4524950-9fa3-36f3-9634-9fcfe40e6dd1

Tian, Y.; \& Steward, C. 2008. History of E-Commerce. Hershey: Idea Group Inc. http://www.irma-international.org/viewtitle/9447/

\section{Aknowledgements}

This article is one of the partial outputs under the scientific research grant VEGA 1/0789/17 „Research of e-commerce with relation to dominant marketing practices and important characteristics of consumer behavior while using mobile device platforms “and VEGA 1/0609/19 „Research on the development of electronic and mobile commerce in the aspect of the impact of modern technologies and mobile communication platforms on consumer behaviour and consumer preferences ".

prof. Ing, Róbert ŠTEFKO, PhD., as a scientist and lecturer, he is a key person at the Faculty of Management of the University of Prešov, and also a dominant development factor of the faculty. He is a professor in the field of management and guarantees all study programs and the educational standards at the Faculty of Management. Currently, he focuses on research in the fields of economics, efficiency, trade and marketing in the area of intangible products and specific services. In the field of marketing theory, he focuses on marketing of specific intangible products (and related economic-management areas) and on its application in Slovak and foreign practice, he also established a scientific school.

ORCID ID: orcid.org/0000-0003-0877-8880

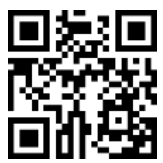

doc. PhDr. Radovan BAČíK, PhD., he has been working as a lecturer at the Department of Marketing and International Trade of the University of Prešov since 2009. Also, since 2013, he has been working as the Head of the before mentioned department. In 2011 he took a degree of Master of Business Administration at the Sales Manager Academy, Vienna. In his research activities he is focusing on areas such as marketing, public relations, strategic marketing, communication in management and branding.

ORCID ID: orcid.org/0000-0002-5780-3838 


\section{ENTREPRENEURSHIP AND SUSTAINABILITY ISSUES}

ISSN 2345-0282 (online) http://jssidoi.org/jesi/ 2019 Volume 7 Number 1 (September) http://doi.org/10.9770/jesi.2019.7.1(2)

Mgr. Richard FEDORKO, PhD., he has been working as a lecturer at the Department of Marketing and International Trade of the University of Prešov since 2014. In his research activities he is focusing on the issues of online marketing and e-commerce, especially on the fields of online advertising, online reputation, social media, customer support, consumer behaviour and mobile marketing.

ORCID ID: orcid.org/0000-0003-3520-1921

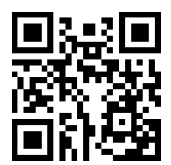

Mgr. Mária OLEÁROVÁ, in 2016 she started her doctoral studies at the Department of Marketing and International Trade at the Faculty of Management of the University of Prešov. Her research fields include mainly digital marketing, especially the trends in marketing communications. A significant part of her research is also related to mobile marketing.

ORCID ID: orcid.org/0000-0001-9086-7975

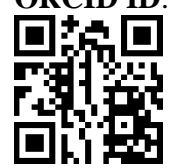

Mgr. Martin RIGELSKÝ, in 2017 he started his doctoral studies at the Department of Marketing and International Trade at the Faculty of Management of the University of Prešov. His research activities primarily focus on social research in economic sciences and sciences connected to management and marketing. For a longer period of time, he has been focusing on the behavioural concept of the customer in e-commerce.

ORCID ID: orcid.org/0000-0003-1427-4689

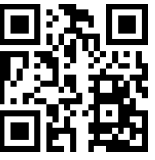

Copyright (C) 2019 by author(s) and VsI Entrepreneurship and Sustainability Center

This work is licensed under the Creative Commons Attribution International License (CC BY).

http://creativecommons.org/licenses/by/4.0/

c) (†) Open Access 